\title{
Testosterone and $5 \alpha$-dihydrotestosterone production in vitro by rat testicular tissue treated with oestradiol-17 $\beta$
}

\author{
J. R. Wisner, Jr and S. I. Fox \\ Department of Physiology, University of Southern California, School of Medicine, \\ Los Angeles, California 90033, U.S.A.
}

\begin{abstract}
Summary. Decapsulated adult rat testes were assessed for their capacity to produce testosterone and $5 \alpha$-dihydrotestosterone when incubated in the presence of oestradiol- $17 \beta$ for $3 \mathrm{~h}$. Concentrations of $10^{-6}$ and $10^{-8} \mathrm{M}$-oestradiol-17 $\beta$ had no significant effect on the production of these hormones and did not alter the capacity of the testes to respond to $100 \mathrm{i} . \mathrm{u}$. hCG in vitro. It is suggested that oestradiol-17 $\beta$ does not directly affect acute regulation of testicular steroidogenesis in the adult rat.
\end{abstract}

\section{Introduction}

Prolonged administration of oestrogens to intact adult male animals results in diminished testicular androgen production and cessation of spermatogenesis (Steinberger, 1971), but controversy has developed over whether such effects are secondary to oestrogenic suppression of pituitary gonadotrophins or are due, at least in part, to a direct effect of oestrogens on the testes. Daily administration of oestrogens to intact adult male rats results in decreased plasma and testicular testosterone concentrations, but no discernible change in circulating LH or FSH levels (Danutra et al., 1973; Chowdhury, Tcholakian \& Steinberger, 1974; Moger, 1976). Other workers, however, have shown that while plasma testosterone is reduced in oestrogen-treated male rats, such reductions appear to be due to suppression of plasma LH concentrations (Verjans, de Jong, Cooke, van der Molen \& Eik-Nes, 1974; de Jong, Uilenbroek \& van der Molen, 1975; van Beurden, Mulder, de Jong \& van der Molen, 1977). Since many of these experiments employed similar dosages and time courses of administration of oestrogens the reasons for such conflicting results are not apparent. However, Lee, Bird \& Clark (1975) reported that oestradiol-17 $\beta$ appears to increase the metabolic clearance rate of testosterone in male rats and such a change could affect the results of in-vivo studies of testicular testosterone production. While the present work was in progress, Bartke, Williams \& Dalterio (1977) reported that rat testes incubated in vitro in the presence of hCG and $10^{-5} \mathrm{M}$-oestradiol-17 $\beta$ released testosterone in amounts similar to those produced by testes incubated without oestradiol-17 $\beta$, although hCG and $10^{-4}$ M-oestradiol-17 $\beta$ significantly reduced testosterone production. The present study confirms and extends the experiments of Bartke et al. (1977) in that different concentrations of oestradiol were tested and the production of $5 \alpha$-dihydrotestosterone was also examined.

\section{Materials and Methods}

Experiment 1 . Adult male Sprague-Dawley rats $(375-400 \mathrm{~g}$ body weight) were killed by decapitation between 12:00 and 14:00 $\mathrm{h}$ and the testes were rapidly removed, decapsulated and weighed. Alternating right and left testes were transferred to $25 \mathrm{ml}$ Erlenmeyer flasks containing $2 \mathrm{ml}$ Krebs-Ringer-bicarbonate buffer (Umbreit, Burris \& Stauffer, 1972; pH 7.4, 
supplemented with $2 \mathrm{mg}$ glucose $/ \mathrm{ml}$ ) and $10^{-6}$ or $10^{-8} \mathrm{M}$-oestradiol- $17 \beta$ (final concentration: see Table 1) while the contralateral testis of each animal was incubated without oestradiol-17 $\beta$. The tissue was incubated for $3 \mathrm{~h}$ at $33^{\circ} \mathrm{C}$ in a Dubnoff metabolic incubator $(144 \mathrm{cycles} / \mathrm{min})$ under a $95 \% \mathrm{O}_{2}: 5 \% \mathrm{CO}_{2}$ atmosphere. After $30,60,90$ and $180 \mathrm{~min}, 0.25 \mathrm{ml}$ aliquots of incubation media were withdrawn from each flask, transferred to $25 \mathrm{ml}$ conical glass extraction tubes containing $0.5 \mathrm{ml}$ absolute methanol, and stored at $-6^{\circ} \mathrm{C}$ until analysed for testosterone and $5 \alpha$ dihydrotestosterone content. A $0.25 \mathrm{ml}$ volume of the appropriate fresh incubation medium was used immediately to replace the aliquot removed for analysis.

Experiment 2. To investigate the influence of oestradiol-17 $\beta$ on the response of testes to hCG stimulation in vitro, one testis from each rat was incubated (as above) for $1 \mathrm{~h}$ in the presence of $10^{-6} \mathrm{M}$-oestradiol-17 $\beta$ (experimental incubates) while the contralateral testis was incubated in buffer minus oestradiol-17 $\beta$ (control incubates). At the end of the 1-h incubation period, 100 i.u. hCG (Antuitrin "S": Parke Davis \& Co., Detroit, Michigan, U.S.A.) in $0.1 \mathrm{ml} \mathrm{0.9 \%} \mathrm{(w/v)}$ $\mathrm{NaCl}$ were added to the experimental and control flasks, mixed gently by swirling, and incubations continued for an additional $3 \mathrm{~h}$. At the conclusion of the incubations $0.25 \mathrm{ml}$ aliquots of media were withdrawn and stored at $-6^{\circ} \mathrm{C}$ until analysed for steroid content.

Assays. Steroids were extracted from thawed incubate samples with freshly distilled diethyl ether $(3 \times 3$ volumes); testosterone and $5 \alpha$-dihydrotestosterone were separated by celite column chromatography (Nelson, Latham \& Finch, 1975). Testosterone was estimated in duplicate samples by a radioimmunoassay procedure (Finch et al., 1977) employing rabbit antibodies to testosterone-3-oxime thyroglobulin (kindly supplied by Dr R. Horton, University of Southern California School of Medicine). Additionally, because the antibodies to testosterone-3-oxime thyroglobulin exhibit significant ( $>70 \%$ ) cross-reactivity with $5 \alpha$-dihydrotestosterone (Kinouchi, Pages \& Horton, 1973), it was possible to utilize these antibodies for construction of standard curves and duplicate estimation of $5 \alpha$-dihydrotestosterone in chromatographed incubation media extracts. Recoveries of testosterone and 5a-dihydrotestosterone after celite column chromatography of incubation media extracts were $64.3 \pm 2.9 \%$ (mean \pm s.e.m., $n=98$ ) and $32.0 \pm$ $3.6 \%(n=124)$, respectively. Non-specific blanks of the radioimmunoassay methods, based on use of Krebs-Ringer-bicarbonate buffer carried through the entire method, were $6.4 \pm 0.7 \mathrm{pg}$ (mean \pm s.d., $n=6$ ) and $4 \cdot 1 \pm 1 \cdot 1 \mathrm{pg}(n=5)$ for testosterone and $5 \alpha$-dihydrotestosterone, respectively. The sensitivity of the assay methods, calculated as the method blank plus twice the s.d., was $7.8 \mathrm{pg}$ for testosterone and $6.3 \mathrm{pg}$ for $5 \alpha$-dihydrotestosterone. The intra- and interassay coefficients of variation were respectively 6.9 and 12.5 for testosterone and 16.3 and $24.3 \%$ for $5 \alpha$-dihydrotestosterone. Means between experimental and control groups were compared by Student's $t$ test for independent means.

Table 1. Testosterone and $5 \alpha$-dihydrotestosterone concentrations ( $\mathrm{ng} / 2 \mathrm{ml}$ total incubation medium) in incubates of rat testes treated with oestradiol-17 $\beta$

\begin{tabular}{|c|c|c|c|c|c|c|c|c|}
\hline \multirow[b]{3}{*}{ Group } & \multirow{3}{*}{$\begin{array}{l}\text { No. of } \\
\text { testes }\end{array}$} & \multicolumn{7}{|c|}{ Incubation time ( $\mathrm{min})$} \\
\hline & & \multicolumn{4}{|c|}{ Testosterone } & \multicolumn{3}{|c|}{$5 \alpha$-Dihydrotestosterone } \\
\hline & & 30 & 60 & 120 & 180 & 30 & 120 & 180 \\
\hline Control & 10 & $146 \pm 22$ & $164 \pm 22$ & $188 \pm 23$ & $238 \pm 28^{*}$ & $4.9 \pm 0.7$ & $5.4 \pm 1.4 \quad 8.6 \pm 2.5$ & $15 \cdot 6 \pm 2 \cdot 9^{*}$ \\
\hline $\begin{array}{l}10^{-8} \mathrm{M} \\
\quad \text { oestradiol }\end{array}$ & 10 & $130 \pm 24$ & $146 \pm 22$ & $165 \pm 24$ & $173 \pm 26$ & $2 \cdot 7 \pm 1 \cdot 3$ & $9 \cdot 1 \pm 5 \cdot 3 \quad 13 \cdot 0 \pm 5 \cdot 0$ & $18 \cdot 9 \pm 4 \cdot 5^{*}$ \\
\hline $\begin{array}{l}10^{-6} \mathrm{M} \\
\text { oestradiol }\end{array}$ & 10 & $141 \pm 10$ & $203 \pm 18$ & $209 \pm 14$ & $255 \pm 22^{*}$ & $4.4 \pm 1.5$ & $10.9 \pm 3.5 \quad 8.7 \pm 2.0$ & $12 \cdot 6 \pm 4 \cdot 0^{*}$ \\
\hline
\end{tabular}

Values are mean \pm s.e.m.

* Significantly different from 30 min value of that group, $P<0.05$. 


\section{Results}

The results of Exp. 1 are given in Table 1. The increased synthesis of testosterone and $5 \alpha$ dihydrotestosterone after $180 \mathrm{~min}$ are indicative of net synthesis and secretion of steroids under the incubation conditions selected. Testosterone and $5 \alpha$-dihydrotestosterone concentrations in the media from test incubations did not differ $(P>0.05)$ from the corresponding control values at any time. As shown in Table 2, although the presence of oestradiol caused a drop in production of $5 \alpha$-dihydrotestosterone by hCG-stimulated testes, the difference was not significant $(P>0.05)$.

Table 2. Testosterone and $5 \alpha$-dihydro testosterone concentrations $(\mathrm{ng} / 2 \mathrm{ml}$ total incubation medium) in incubates of rat testes treated with oestradiol-17 $\beta$ and hCG

\begin{tabular}{lccc}
\hline \multicolumn{1}{c}{ Treatment } & No. of testes & Testosterone & $5 \alpha$-Dihydrotestosterone \\
\hline Control $+\mathrm{hCG}$ & 5 & $728 \pm 198$ & $137 \pm 46$ \\
Oestradiol $\left(10^{-6} \mathrm{M}\right)+\mathrm{hCG}$ & 5 & $885 \pm 110$ & $75 \pm 22$ \\
\hline
\end{tabular}

Values are mean \pm s.e.m.

\section{Discussion}

In-vitro incubations of decapsulated rat testes have been utilized extensively as a model for investigations of factors regulating testicular biosynthesis of androgens (Dufau, Catt \& Tsuruhara, 1972; Catt \& Dufau, 1974) and this system therefore seemed to be particularly wellsuited for studies to determine whether oestrogens are capable of exerting direct, acute effects on suppression of testicular androgen production. Endogenous oestradiol-17 $\beta$ concentration in the rat testis has been reported to be approximately $40 \mathrm{pg} / \mathrm{g}$ testis (de Jong, Hey \& van der Molen, 1974). The concentrations of $10^{-8} \mathrm{M}^{-}$and $10^{-6} \mathrm{M}$-oestradiol-17 $\beta$ which were used in the present study therefore represent values of approximately 125 and 12500 times the endogenous concentration. Despite this, and the need for caution in extrapolation of data obtained in vitro to the conditions in vivo, the failure of the present studies to demonstrate a suppressive effect of oestradiol-17 $\beta$ on testosterone and $5 \alpha$-dihydrotestosterone production by rat testes in vitro is consistent with the interpretation that the oestradiol suppression of androgen production in vivo is not due to direct inhibition of the testes but to secondary effects such as pituitary inhibition (van Beurden et al., 1977).

The present findings that $10^{-6}$ M-oestradiol- $17 \beta$ (approximately $0.5 \mu \mathrm{g} /$ incubate) did not inhibit testosterone production by decapsulated rat testes in the presence or absence of hCG are fully consistent with the findings of Bartke et al. (1977), but these workers also reported that 300 $\mu \mathrm{g}$ oestradiol-17$\beta$ /incubate resulted in a significant $(38 \%)$ reduction of testosterone production by decapsulated rat testes. This concentration of oestradiol- $17 \beta$ is 600 times the largest concentration of oestradiol-17 $\beta$ used in the present study and about $7.5 \times 10^{6}$ times greater than the endogenous concentration of oestradiol-17 $\beta$ in rat testes (de Jong et al., 1974). While the present work does not exclude the possibility that concentrations of oestradiol- $17 \beta$ in excess of $10^{-6} \mathrm{M}$ in vitro may have a suppressive effect on testicular steroidogenic enzymes (Samuels, Short \& Huseby, 1964), it is questionable whether such concentrations may be achieved in the testes in vivo under physiological conditions (de Jong et al., 1974). It is concluded, therefore, that oestradiol-17 $\beta$ does not appear to participate in the acute regulation of testicular steroidogenesis in the adult rat. 
We thank Dr D. Warren (Department of Physiology, University of Southern California School of Medicine) for his helpful comments during the preparation of this manuscript and Ms Cindy Blees for her careful typing of the manuscript. This work was supported in part by a Biomedical Research Support Grant (No. 5-507-RR0536-16) to J.R.W. from the University of Southern California School of Medicine.

\section{References}

Bartke, A., Williams, K.I.H. \& Dalterio, S. (1977) Effects of oestrogens on testicular testosterone production in vitro. Biol. Reprod. 17, 645-649.

Catt, K.J. \& Dufau, M.L. (1974) Methods for determination of gonadotrophins in vitro-solid phase radioimmunoassay, radioligand-receptor assay and in vitro bioassay. In Recent Progress in Reproductive Endocrinology, pp. 131-162. Eds P. G. Crosignani \& V. H. T. James. Academic Press, New York.

Chowdhury, M., Tcholakian, R. \& Steinberger, E. (1974) An unexpected effect of oestradiol-17 $\beta$ on luteinizing hormone and testosterone. J. Endocr. 60, 375-376.

Danutra, V., Harper, M.E., Boyns, A.R., Cole, E.N., Brownsey, B.G. \& Griffiths, K. (1973) The effect of certain stilboestrol analogues on plasma prolactin and testosterone in the male rat. J. Endocr. 57, 207-215.

de Jong, F.H., Hey, A.H. \& van der Molen, H.J. (1974) Oestradiol-17\% and testosterone in rat testis tissue: effect of gonadotrophins, localization and production in vitro. J. Endocr. 60, 409-419.

de Jong, F.H., Uilenbroek, J.Th. \& van der Molen, H.J. (1975) Oestradiol-17 $\beta$, testosterone and gonadotrophins in oestradiol-17 $\beta$-treated intact adult male rats. J. Endocr. 65, 281-282.

Dufau, M.L., Catt, K.J. \& Tsuruhara, T. (1972) A sensitive gonadotrophin responsive system: radioimmunoassay of testosterone production by the rat testis in vitro. Endocrinology 90, 1032-1040.

Finch, C.E., Jonec, V., Wisner, J.R., Jr, Sinha, Y.N., Devellis, J.S. \& Swerdloff, R.S. (1977) Hormone production by the pituitary and testes of male
C57BL/6J mice during aging. Endocrinology 101 , $1310-1317$.

Kinouchi, T., Pages, L. \& Horton, R. (1973) A specific radioimmunoassay for testosterone in peripheral plasma. J. Lab. Clin. Med. 82, 309-316.

Lee, D.K.H., Bird, C.E. \& Clark, A.F. (1975) In vivo metabolism of ${ }^{3} \mathrm{H}$-testosterone in adult male rats: effects of oestrogen administration. Steroids 26, $137-147$.

Moger, W.H. (1976) Serum testosterone response to acute LH treatment in oestradiol treated rats. Biol. Reprod. 14, 222-232.

Nelson, J.F., Latham, K.R. \& Finch, C.E. (1975) Plasma testosterone levels in C57BL/6J male mice: effects of age and disease. Acta endocr., Copenh. 80, 744752 .

Samuels, L.T., Short, J.G. \& Huseby, R.A. (1964) The effects of diethylstilboestrol on testicular $17 \alpha$ hydroxylase and 17-desmolase activities in $\mathrm{Balb} / \mathrm{c}$ mice. Acta endocr., Copenh. 45, 487-497.

Steinberger, E. (1971) Hormonal control of mammalian spermatogenesis. Physiol. Rev. 51, 1-22.

Umbreit, W.W., Burris, R.H. \& Stauffer, J.F. (1972) Manometric and Biochemical Techniques, 5th edn, p. 146. Burgess, Minneapolis.

van Beurden, W.O., Mulder, E., de Jong, F.H. \& van der Molen, H.J. (1977) The effect of oestrogens on luteinizing hormone plasma levels and on testosterone production in intact and hypophysectomized rats. Endocrinology 101, 342-349.

Verjans, H.L., de Jong, F.H., Cooke, B.A., van der Molen, H.J. \& Eik-Nes, K.B. (1974) Effect of oestradiol benzoate on pituitary and testis function in the normal adult male rat. Acta endocr., Copenh. $77,636-642$. 